\title{
Consumption of drift kelp by intertidal populations of the sea urchin Tetrapygus niger on the central Chilean coast: possible consequences at different ecological levels
}

\author{
Sebastián R. Rodríguez ${ }^{1,2, *}$ \\ ${ }^{1}$ Departamento de Ciencias Básicas, Universidad Santo Tomas, Ejército 146, Santiago, Chile \\ ${ }^{2}$ Center for Advanced Studies in Ecology \& Biodiversity, Facultad de Ciencias Biológicas, P. Universidad Católica de Chile, \\ Casilla 114-D, Santiago, Chile
}

\begin{abstract}
Drift algae are an important food resource for many intertidal marine invertebrates. This study quantifies the arrival rate of drift kelp on the intertidal zone of central Chile and analyses its nutritional role in maintaining populations of the sea urchin Tetrapygus niger. The analysis was based on stomach contents and on stable isotope ratios of the food and the sea urchin. Gonad development was also evaluated. Lessonia nigrescens was the kelp most commonly observed, and its arrival pattern showed both temporal and spatial variation. The highest levels of drift kelp occurred in late spring, early summer and part of the autumn. Lessonia spp. were the most important food of T. niger, comprising $68 \%$ of the diet, and most of the assimilated carbon came from this source. The availability of drift kelp influenced gonad development. Trophic subsidies such as drift kelp are clearly important to intertidal animals of temperate ecosystems and have effects at different levels of biological organization. Two alternative scenarios of community organization are proposed for tidepools, depending on drift kelp availability.
\end{abstract}

KEY WORDS: Drift kelp · Rocky substratum - Tidepools · Sea urchins - Gonad development · Community structure

Resale or republication not permitted without written consent of the publisher

\section{INTRODUCTION}

The production of detached brown macroalgae and their arrival on the intertidal zone are processes which exhibit temporal variations as a consequence of different biotic and abiotic factors, e.g. water movement (Gerard 1976, Harrold \& Reed 1985, Tegner \& Dayton 1987, 1991, Dayton et al. 1992). Most macroalgae drift to rocky or sandy beaches, where they become important energy sources for invertebrates (Inglis 1989, Bustamante et al. 1995).

Drift algae represent the most important food for many marine species such as polychaetes (e.g. Magnum \& Cox 1971), limpets (e.g. Bustamante et al. 1995), abalone (e.g. Tutschulte \& Connell 1988), sea urchins (e.g. Castilla \& Moreno 1981, Dayton et al. 1984, Harrold \& Reed 1985) and seastars (e.g. Gerard 1976).
Despite this, the consequences of consumption of this resource for populations and/or communities have been little explored. Dynamics of some food webs depend on trophic subsidies (Polis et al. 1995, 1997). On sandy beaches, detached macroalgae can represent a fundamental organic contribution to many consumers, e.g. amphipods (Duarte 1974, Inglis 1989). After decomposition by microbes and abiotic fragmentation, part of the energy of drift macroalgae is eventually incorporated into the interstitial trophic chains of these environments (Inglis 1989). Some studies have highlighted the importance of detached macroalgae to secondary production in marine habitats (e.g. high biomass of limpets, Bustamante et al. 1995; large size of polychaetes, Kim 1992; abundance of non-urchin megafauna and fishes in submarine canyons, Vetter \& Dayton 1999) or terrestrial systems (e.g. high density of 
spiders; Polis \& Hurd 1995, Anderson \& Polis 1998). These works emphasize that changes in abundance, size and/or biomass of consumers could indicate how consumption of drift macroalgae would trigger changes in the structure of a community. Eating detached macroalgae could also modify reproduction, and therefore population and/or community patterns. Development of gonads in some sea urchins is limited by the quantity and quality of food available (Russell 1998), which in many cases corresponds to drift algae.

The sea urchin Tetrapygus niger is a conspicuous arbacioid occurring on the temperate south Pacific coast from the intertidal zone to $40 \mathrm{~m}$ depth (Larraín 1975). This urchin mainly consumes turfing algae (Contreras \& Castilla 1987). Moreover, it has been considered unable to use drift algae as an important food item because it lacks the morphological structures necessary to capture this kind of resource (Vásquez 1986, Contreras \& Castilla 1987). Vásquez (1993) has, however, suggested that this morphological deficiency could be overcome, in part, through the aggregation of individuals, which increases the probability of retaining drift material among spines. Some populations of this species are not found in the field together with those algae most commonly found in their diets, suggesting that $T$. niger could eat drift material (Roa 1990).

The arrival of drift kelp on the coast and the availability of this resource to intertidal consumers have received little attention in temperate environments. In the present study, the spatial and temporal patterns of arrival of drift macroalgae on the temperate coast of central Chile were recorded and the availability of this resource to intertidal populations of the sea urchin Tetrapygus niger was estimated. The effect of the consumption of drift kelp on the production of gonads was also investigated. The importance of shifting from eating benthic algae to eating drift kelp is discussed.

\section{MATERIALS AND METHODS}

Arrival of drift kelp in intertidal habitats. The amount of kelp arriving was measured at 3 sites on the central Chilean coast: 2 near Punta de Tralca $\left(33^{\circ} 35^{\prime} \mathrm{S}\right.$, $71^{\circ} 42^{\prime} \mathrm{W}$ ) and 1 near El Tabo (33 $27^{\prime} \mathrm{S}, 71^{\circ} 38^{\prime} \mathrm{W}$ ). One of the sites near Punta de Tralca is a bay characterized by a kelp forest of Lessonia trabeculata in the shallow subtidal zone. This site (PTp) has calm water for most of the year. In contrast, the second site near Punta de Tralca, in the south of the bay (PTse), has no subtidal kelp forest and is subject to intense surge for most of the year. The site near El Tabo (TNse) has a small shallow kelp forest of Macrocystis pyrifera and has a strong surge similar to that at PTse. L. nigrescens was observed in the low intertidal zone at every site.
Three permanent quadrats of $100 \mathrm{~m}^{2}$ (i.e. $10 \mathrm{~m}$ per side) were established between the high and low tide limits at each site. The quadrats were sampled once a month from May 1996 to April 1997, with the exception of August 1996 and February 1997 when tide, waveaction and other environmental conditions prevented it. At each time, the drift kelp found in quadrats was weighed and then discarded.

In order to compare the total average biomass of drift macroalgae deposited at Punta de Tralca and El Tabo, at the sites with and without kelp forests, or with different wave-action levels, 1-way factorial ANOVAs were performed. Likewise, to compare the total average biomass of drift kelp deposited in different months, 1-way repeated-measures ANOVAs were carried out. In some cases a Fisher's PLSD test was used as an a posteriori test (Sokal \& Rohlf 1995). The different factors were separately analyzed because the sampling design prevented a simultaneous consideration of all of them.

The amount of drift kelp was also measured in 8 tidepools selected from 3 localities on the central Chilean coast: Las Cruces $\left(33^{\circ} 30^{\prime} \mathrm{S}, 71^{\circ} 30^{\prime} \mathrm{W}_{\text {; }}\right.$ hereafter $\mathrm{LC}_{1}$, $\mathrm{LC}_{2}, \mathrm{LC}_{3}$ and $\left.\mathrm{LC}_{4}\right)$, El Quisco $\left(33^{\circ} 23^{\prime} \mathrm{S}, 71^{\circ} 42^{\prime} \mathrm{W}\right.$; hereafter $\mathrm{EQ}_{1}$ ) and $\mathrm{El}$ Tabo (hereafter $\mathrm{ET}_{1}, \mathrm{ET}_{2}$ and $\mathrm{ET}_{3}$ ). Tidepools were chosen taking into account the location in the rocky intertidal zone (medium or low intertidal), the presence of a sea urchin population of Tetrapygus niger and the absence of kelp species attached to rock. The surface area and volume of each pool were calculated (they varied from 3.6 to $19.7 \mathrm{~m}^{2}$ and from 2.3 to $15.8 \mathrm{~m}^{3}$ respectively), and the density of $T$. niger was estimated in random $0.25 \mathrm{~m}^{2}$ quadrats or by dividing the total number of individuals by the surface area of the pool (it varied from 2 to 85 ind. $\mathrm{m}^{-2}$ ). Tidepools were sampled every 45 d from June 1997 to April 1998. At each time, drift kelp was weighed and discarded.

Availability of drift kelp to intertidal sea urchins. The ability of Tetrapygus niger to retain fronds deposited in tidepools was experimentally estimated. For this, Lessonia nigrescens fronds, previously marked with coloured cords, were introduced in the same 8 intertidal pools described above. The average wet weight of fronds introduced in pools was $355.5 \pm 19.7 \mathrm{~g}$. After $24 \mathrm{~h}$, the biomass of fronds found under the bodies or among the spines of sea urchins was quantified.

In order to estimate the availability of drift kelp per individual (DKA, $g$ ind. ${ }^{-1}$ ), the biomass of fronds deposited in each tidepool was divided by the number of sea urchins. To determine if the availability of drift kelp was sufficient or insufficient to feed the sea urchin populations of tidepools, the DKA was contrasted with the daily individual consumption rate of Tetrapygus niger. This was estimated using the feeding preference data obtained by Roa (1992) for medium-sized individuals (test diameter [TD] ca. $60 \mathrm{~mm}$ ) fed with different spe- 
cies of algae ( $0.326 \mathrm{~g}$ wet weight algae ind..$\left.^{-1} \mathrm{~d}^{-1}\right)$. This analysis assumes that a sufficient availability of drift kelp in quantitative terms corresponds to a sufficient availability in qualitative terms (nutritional quality).

Diet. The diet of intertidal Tetrapygus niger was analyzed from the gut contents of 58 adult individuals (average TD $56.2 \pm 8.3 \mathrm{~mm}$ ) collected during autumn 1996 and autumn 1997 from tidepools at Las Cruces $\left(\mathrm{LC}_{1}, \mathrm{LC}_{2}\right.$ and $\left.\mathrm{LC}_{3}\right)$, El Quisco $\left(\mathrm{EQ}_{1}\right)$, El Tabo $\left(\mathrm{ET}_{1}\right)$ and Los Molles $\left(32^{\circ} 15^{\prime} \mathrm{S}, 71^{\circ} 30^{\prime} \mathrm{W}_{\text {; }}\right.$ hereafter $\mathrm{LM}_{1}$ and $\left.\mathrm{LM}_{2}\right)$. No differences in diet were observed among years. All tidepools were dominated by green (Ulva spp. and Enteromorpha spp.) and calcareous crustose algae and were characterized by the absence of attached brown macroalgae. Likewise, in all pools Lessonia nigrescens was the main drift species ( $>80 \%$ of total drift macroalgal biomass). The diet of 22 adult sea urchins (average TD $62.5 \pm$ $5.8 \mathrm{~mm}$ ) collected during late autumn 1997 from low intertidal areas of Punta de Tralca (PTse) was also studied. This site was dominated by calcareous crustose algae.

Diet was analysed using the method described by Castilla \& Moreno (1981) and Vásquez et al. (1984). Each gut content was standardized to $60 \mathrm{ml}$ with formol saline. Subsamples of $5 \mathrm{ml}$ were taken from each sample and placed in a petri dish (diameter $5 \mathrm{~cm}$ ) with 36 intersection points on it. The items observed at the intersection points were identified to the lowest taxonomic level. The analysis continued until at least 50 intersections with material were recorded. The relative abundance of each food item was described with respect to the total number of intersection points analyzed in each tidepool $\left(\mathrm{R}_{\mathrm{a}}, \%\right)$.

Analysis of stable isotope ratios of carbon and nitrogen. Samples of different algae and Tetrapygus niger were collected from tidepools at Las Cruces $\left(\mathrm{LC}_{1}\right.$ and $\mathrm{LC}_{3}$ ) and El Tabo $\left(\mathrm{ET}_{1}\right)$ and from the low intertidal zone at PTse. The muscles of the Aristotle's lantern were extracted. Samples were washed with distilled water and dried at $60^{\circ} \mathrm{C}$ to constant weight (48 to $72 \mathrm{~h}$ ). The dry samples were ground and sent to Geochron Laboratories (USA) for stable isotopic analysis (McConnaughey \& McRoy 1979, Rau et al. 1983, Rounick \& Winterbourn 1986).

The isotopic value of each sample was calculated using the formula:

$$
\left.\delta \mathrm{X}(\%)=\left[\left(\mathrm{R}_{\text {sample }}-\mathrm{R}_{\text {standard }}\right) / \mathrm{R}_{\text {standard }}\right)\right] \times 1000
$$

where $\delta \mathrm{X}=\delta^{13} \mathrm{C}$ or $\delta^{15} \mathrm{~N}$ and $\mathrm{R}={ }^{13} \mathrm{C}:{ }^{12} \mathrm{C}$ or ${ }^{15} \mathrm{~N}:{ }^{14} \mathrm{~N}$. The nitrogen and carbon standards were the air and PDB (Pee Dee Belemnite) respectively. The spectrometer precision for each isotopes was close to $\pm 0.08 \%$. The precision of the total method (i.e. preparation and analysis) was close to $\pm 0.4 \%$ for nitrogen and $\pm 0.3 \%$ o for carbon. Ten percent of samples and suspicious results were replicated.
The natural fractionation index for the trophic level of herbivores was estimated from the nitrogen and carbon stable isotope values of Lessonia nigrescens (primary producer) and Scurria scurra, a limpet that uses L. nigrescens as its main food resource (Muñoz \& Santelices 1989). The fractionation was 2.7 and 5.0 for nitrogen and carbon respectively. These values were used to correct the stable isotope values of sea urchins and to contrast them with those obtained from the different food sources, i.e. algae.

The species of algae from El Tabo (Gelidium spp., Ulva spp. and Lessonia nigrescens) showed values of nitrogen and carbon stable isotopes larger than those from Las Cruces and Punta de Tralca. Therefore, data from this locality were analyzed separately. It is likely that the productivity and the hydrodynamic environment, both of which affect fractionation, were responsible for the results at this locality (Simenstad et al. 1993). The algae of the same species from Las Cruces and Punta de Tralca were pooled. The same was done with the green algae Ulva spp. and Enteromorpha spp., which showed similar values in all localities.

Drift kelp and development of gonads. The effects of eating drift kelp on the gonads of Tetrapygus niger were evaluated during early spring 1998 in 4 tidepools at Las Cruces (individuals reach the peak of gonad maturity during late winter and spawn during spring, see Zamora \& Stotz 1993). All tidepools were dominated by green (Ulva spp. and Enteromorpha spp.) and calcareous crustose algae. Two of them, however, had no drift kelp throughout the study $\left(\mathrm{LC}_{1}\right.$ and $\left.\mathrm{LC}_{4}\right)$ while the others always had this resource $\left(\mathrm{LC}_{2}\right.$ and $\mathrm{LC}_{3}$, see Fig. 2). After collection, the test diameter of individuals and the wet weight of gonads were measured.

Data were ln-transformed, and an ANCOVA was performed to compare the wet weight of gonads in sea urchins from tidepools with high and low availability of drift kelp, considering the $\ln$ (test diameter) as the covariate. They were also compared to those obtained from sea urchins collected during early spring from the low intertidal zone of PTse, a site widely dominated by calcareous crustose algae and a low presence of drift kelp. A slope homogeneity test was carried out for each ANCOVA (Sokal \& Rohlf 1995) but no significant differences were detected ( $p>0.3$ in both cases). When necessary, the Bonferroni method was used as an a posteriori test. Taking into account that gonads are absent in sea urchins until they reach a given size, a fitted allometric equation was used to determine the relationship between the wet weight of gonads and the size of individuals (Russell 1998). This equation takes the form $y=\alpha(x-\gamma)^{\beta}$, where $y=$ wet weight of gonads, $x$ $=$ test diameter, and $\gamma=$ test diameter at which sea urchins start to develop gonadal tissue (ca. $25 \mathrm{~mm}$ in the case of $T$. niger). 


\section{RESULTS}

\section{Arrival of drift kelp and availability to sea urchins}

The results show that drift kelp was constantly arriving on the intertidal zone of the central Chilean coast (rocky substratum and tidepools). The species most commonly found was Lessonia nigrescens, representing 72 to $74 \%$ of the total biomass. It was followed by Lessonia trabeculata, representing 20 to $22 \%$, and Macrocystis pyrifera, representing 5.8 to $6.8 \%$ of the total biomass.

The average biomass of drift kelp was significantly different at the 3 study sites $(F=39.3, \mathrm{p}<0.05)$ (i.e. high inter-site variability) and showed important variations among neighbouring quadrats (i.e. high intra-site variability, especially TNse) (Fig. 1). The highest levels of drift kelp were observed at PTp with averages ca. $340 \mathrm{~g} \mathrm{~m}^{-2}$ (Fig. 1). Arrival of drift macroalgae at this site was significantly higher than arrival at TNse, in spite of the presence of a subtidal forest at both sites $(F=23.1, \mathrm{p}<0.01)$. TNse showed an average biomass of drift kelp ca. $112 \mathrm{~g} \mathrm{~m}^{-2}$ (Fig. 1), which was significantly higher than average biomass at PTse $\left(4.1 \mathrm{~g} \mathrm{~m}^{-2}\right)$, in spite of both sites presenting similar wave-action intensities $(F=11.9, \mathrm{p}<0.01)$ (Fig. 1). The residence time of drift macroalgae was related to the wave-action level at sites (high at PTp and low at PTse and TNse; data not shown). A high inter- and intra-site variability in the arrival of drift kelp was also observed in tidepools (Fig. 2).

The amount of drift macroalgae observed every month showed important temporal variations at all the study sites (Fig. 1). In general, the highest levels of drift kelp arrival were observed during late spring, early summer and part of the autumn, while the lowest levels occurred during winter and early spring. In PTp the arrival of drift kelp was significantly higher in May, November and December 1996 and April 1997 than in August-September and October 1996 and February-March $1997(F=6.9, \mathrm{p}<0.05)$ (Fig. 1). At PTse the arrival of drift macroalgae was significantly higher in May and December 1996, and January and April 1997, than in June, July, August-September, October and November 1996 ( $F=8.0, \mathrm{p}<0.05)$ (Fig. 1). In contrast, TNse showed no significant differences in drift kelp arrival over time, although this site presented high values in June, July and November 1996 and April 1997 (Fig. 1). In tidepools the temporal pattern of drift kelp arrival also showed low levels during late winter and early spring, and high levels during summer and autumn (see 'Total' in Fig. 2).

The Tetrapygus niger individuals were able to retain $32 \%$ of the total biomass of algae initially placed in tidepools. This percentage was close to $82 \%$ when the biomass of algae initially placed in tidepools and remaining there throughout the experiment was considered $(45 \%$ of the initial biomass remained in tidepools during the experiment).

The availability of drift kelp was higher than the daily consumption rate per individual Tetrapygus niger. In general, the DKA was not enough to feed sea urchin populations during late winter and early spring (i.e. September and October 1997) and sufficient to feed sea urchin populations during a large part of the summer and autumn (i.e. December 1997, February and April 1998). The DKA was permanently insufficient to feed sea urchin populations in 2 tidepools where the arrival of drift kelp was $<1 \mathrm{~g} \mathrm{~m}^{-2}$ or zero $\left(\mathrm{LC}_{1}\right.$ and $\left.\mathrm{LC}_{4}\right)$ during the whole study.

\section{Consumption of drift kelp by sea urchins and effects on gonad development}

Kelp (Lessonia spp.) was the main food item in the natural diet of intertidal Tetrapygus niger individuals. Its relative abundance in the diet of this species was $68 \%$, varying from 20 to $92 \%$ in the different tidepools (Table 1). Second in importance was the green alga Ulva spp., with a relative abundance of $10 \%$ (Table 1). Other items with relatively high percentages were the green algae Enteromorpha spp. and Ulothrix sp. (5.5 and 5.8\% respectively) and calcareous crustose algae $(2.5 \%)$ (Table 1). The diet of intertidal sea urchins collected from PTse, however, showed a clear predominance of calcareous crustose algae, with a relative abundance of $44 \%$, followed by the kelp Lessonia spp. and the green alga Ulva spp., with values of 13 and $11 \%$ respectively (Table 1).

The nitrogen and carbon stable isotope values of different species of algae collected from tidepools at Las Cruces and the low intertidal zone of PTse are shown in Fig. 3a. In $\mathrm{LC}_{3}$, the carbon assimilated by Tetrapygus niger was almost exclusively derived from kelp, mainly Lessonia nigrescens (Fig. 3b). In contrast, the carbon assimilated by sea urchins in the tidepool $\mathrm{LC}_{1}$ was almost exclusively derived from Ulva spp. and Enteromorpha spp. (Fig. 3b). In the tidepool $\mathrm{ET}_{1}$, the carbon assimilated by $T$. niger was totally derived from the kelp L. nigrescens (Fig. 3c). Finally, the carbon assimilated by intertidal sea urchins at PTse was probably derived from calcareous crustose algae and green algae (Fig. 3b). In all the above cases, the nitrogen assimilated was apparently derived from a combination of different sources (Fig. 3).

ANCOVA showed that the wet weight of gonads was significantly higher in sea urchins from tidepools exposed to a high drift kelp availability than in those from tidepools exposed to a low availability $\left(F_{1,56}=\right.$ 
4.79, p < 0.05) (Fig. 4). This difference was particularly evident for individuals $>50 \mathrm{~mm}$ TD (Fig. 4). The importance of kelp availability in the development of gonadal tissue was corroborated when the sea urchins from tidepools were compared to those from PTse (a site with a low drift kelp arrival and a sea urchin population with a diet mainly based on calcareous crustose
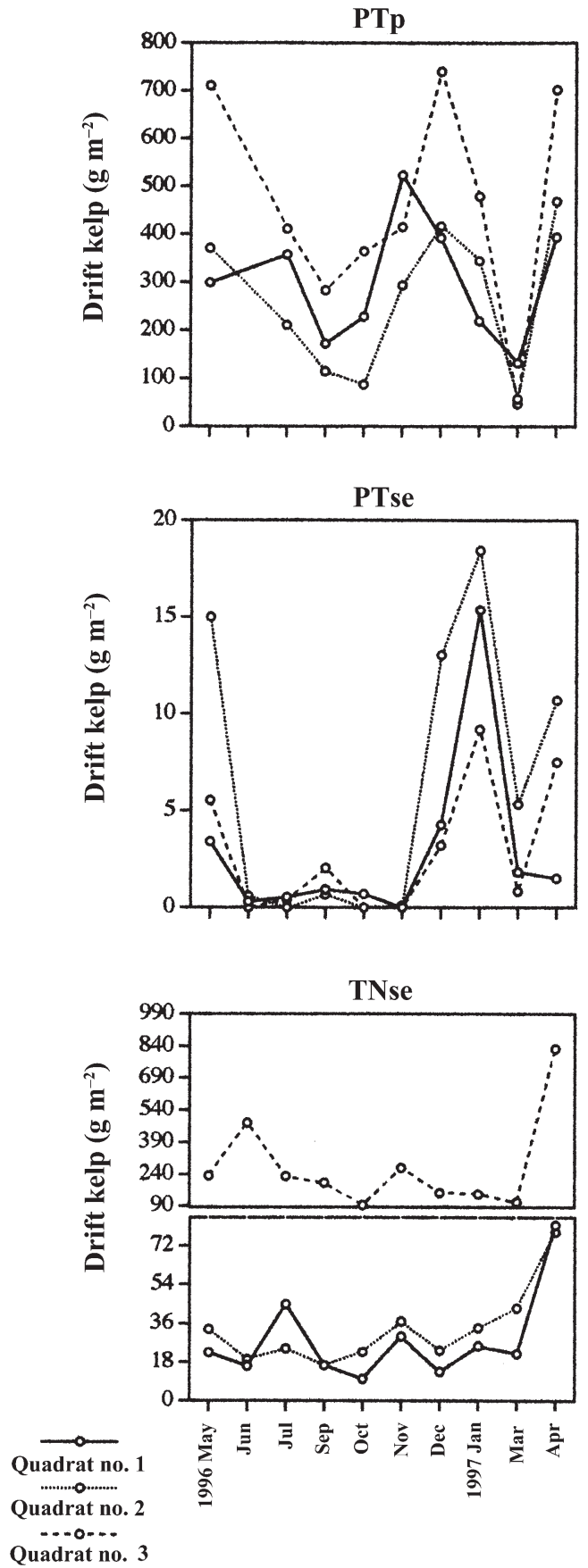

Fig. 1. Temporal patterns of drift kelp fronds deposited on intertidal rocky substratum in 3 sites on the central Chilean coast
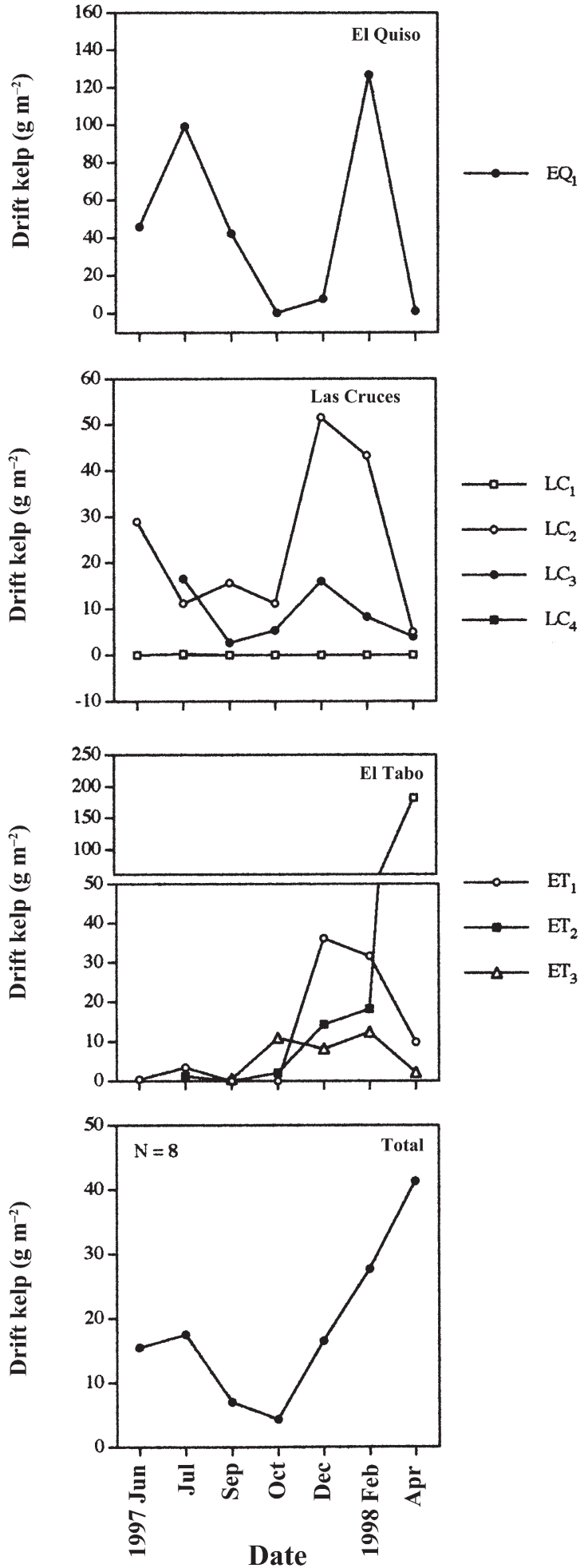

Fig. 2. Temporal patterns of drift kelp fronds deposited in tidepools at 3 sites on the central Chilean coast. Each abbreviation corresponds to a different tidepool. The average of deposited drift kelp fronds considering all tidepools is also shown. The variance has been omitted in order to highlight the temporal pattern. $\mathrm{N}=$ total number of tidepools 
Table 1. Relative abundance $\left(\mathrm{R}_{\mathrm{a}}, \%\right)$ of different prey items found in the digestive contents of Tetrapygus niger individuals from different tidepools on the central Chilean coast. $\mathrm{LM}=$ Los Molles, $\mathrm{LC}=$ Las Cruces, EQ $=\mathrm{El}$ Quisco, ET $=\mathrm{El}$ Tabo, and PTse $=$ 1 of the 2 sites near Punta de Tralca (see text)

\begin{tabular}{|c|c|c|c|c|c|c|c|c|c|}
\hline Prey items & $\begin{array}{c}\mathrm{LM}_{1} \\
(\mathrm{n}=6)\end{array}$ & $\begin{array}{c}\mathrm{LM}_{2} \\
(\mathrm{n}=6)\end{array}$ & $\begin{array}{c}\mathrm{LC}_{1} \\
(\mathrm{n}=9)\end{array}$ & $\begin{array}{c}\mathrm{LC}_{2} \\
(\mathrm{n}=5)\end{array}$ & $\begin{array}{c}\mathrm{LC}_{3} \\
(\mathrm{n}=20)\end{array}$ & $\begin{array}{c}\mathrm{EQ}_{1} \\
(\mathrm{n}=6)\end{array}$ & $\begin{array}{c}\mathrm{ET}_{1} \\
(\mathrm{n}=6)\end{array}$ & $\begin{array}{l}\text { TOTAL } \\
(\mathrm{n}=58)\end{array}$ & $\begin{array}{c}\text { PTse } \\
(\mathrm{n}=22)\end{array}$ \\
\hline \multicolumn{10}{|l|}{ Brown algae } \\
\hline Lessonia spp. & 83.9 & 63.3 & 44.1 & 70.1 & 82.6 & 91.5 & 20.3 & 68.47 & 13.4 \\
\hline Macrocystis spp. & & 1.3 & & & & & & 0.16 & 2.9 \\
\hline Glossophora sp. & 0.9 & 0.3 & 1.3 & 1.8 & 1.1 & 6.4 & 2.2 & 1.72 & 4.2 \\
\hline Colpomenia spp. & & 0.5 & 1.5 & & 0.2 & & & 0.34 & \\
\hline Scytosiphon sp. & & & 0.2 & & & & & 0.03 & \\
\hline Halopteris sp. & & & 0.2 & & & & & 0.03 & \\
\hline Order Ectocarpales & & & 0.2 & 0.7 & & & & 0.09 & 0.1 \\
\hline \multicolumn{10}{|l|}{ Red algae } \\
\hline Gelidium spp. & & 2.4 & 0.9 & 2.2 & 1.2 & & & 1.00 & 3.8 \\
\hline Porphyra spp. & & & & & 0.3 & & & 0.09 & 0.1 \\
\hline Mazzaella sp. & & & 0.2 & & 0.4 & & & 0.16 & \\
\hline Plocamiun spp. & & & 0.5 & 2.2 & 0.2 & & 0.4 & 0.34 & 0.3 \\
\hline Gastroclonium spp. & & & 0.2 & & 0.1 & & & 0.06 & \\
\hline Hildenbrandia sp. & & & & & & & & & 7.3 \\
\hline Chondrus canaliculatus & & & & & & & & & 3.9 \\
\hline Corallina spp. & & & 0.4 & 2.2 & & & & 0.25 & \\
\hline Calcareous crustose algae & & & 1.5 & 12.9 & & 0.9 & 10.9 & 2.54 & 43.9 \\
\hline Order Ceramiales & 0.3 & 1.1 & 3.7 & & 3.4 & 1.2 & & 1.97 & 4.8 \\
\hline \multicolumn{10}{|l|}{ Green algae } \\
\hline Ulva spp. & 13.1 & 24.2 & 10.6 & 3.2 & 10.0 & & 7.1 & 10.16 & 10.9 \\
\hline Enteromorpha spp. & 1.2 & 6.4 & 22.2 & 0.7 & 0.4 & & 11.9 & 5.50 & 1.6 \\
\hline Codium spp. & & & 1.5 & & & & & 0.22 & \\
\hline Chaetomorpha spp. & 0.3 & 0.5 & & & & & & 0.10 & 0.1 \\
\hline Rhizoclonium sp. & & & & & 0.1 & & & 0.03 & 0.1 \\
\hline Ulothrix sp. & & & 8.4 & 0.4 & & & 45.0 & 5.80 & \\
\hline Others & & & 0.6 & 2.9 & & & 1.6 & 0.50 & 0.5 \\
\hline Non-identified & 0.3 & & 1.8 & 0.7 & & & 0.6 & 0.44 & 2.1 \\
\hline Total & 100.0 & 100.0 & 100.0 & 100.0 & 100.0 & 100.0 & 100.0 & 100.0 & 100.0 \\
\hline
\end{tabular}

algae). The ANCOVA showed that the wet weight of gonads was significantly lower in sea urchins from PTse than in individuals from tidepools exposed to some level of drift kelp availability $\left(F_{2,82}=22.02\right.$, $\mathrm{p}<0.001$ ) (Fig. 4).

\section{DISCUSSION}

\section{Arrival patterns of drift kelp and availability to sea urchins}

Drift kelp was constantly arriving on the intertidal zone of the central Chilean coast during this study. However, a high inter- and intra-site variability was observed in the arrival pattern. Gerard (1976) showed that substratum and topography had a large influence in the distribution pattern of drift Macrocystis pyrifera in California, i.e. large numbers of fronds were observed in areas where the water movement was slow or where physical barriers prevented the movement of algae. Vetter \& Dayton (1999) showed that submarine canyons could accumulate large quantities of food in aggregated form (as pieces or entire plants of drift algae and surfgrass) on the deep-sea floor by acting as conduits for marine macrophyte production from the intertidal and shallow subtidal zone. It is likely that hydrographic (e.g. wave action) and topographic (e.g. substratum heterogeneity) factors, as well as the presence or absence of a subtidal kelp forest, play an important role in determining the variability of algae on the central Chilean coast. PTp for example, the site in this study that was characterized by a subtidal kelp forest and calm waters for most of the year, showed the highest level of drift kelp arrival. In contrast, the site without a subtidal kelp forest but with intense wave action for most of the year (PTse), showed the lowest level of drift kelp arrival. TNse, the site characterized by a subtidal kelp forest and intense wave action (similar to PTse), showed intermediate levels of drift kelp arrival. The role of wave action, topography and the presence or absence of a subtidal kelp forest in determining drift kelp arrival patterns in intertidal zones will require further studies. 

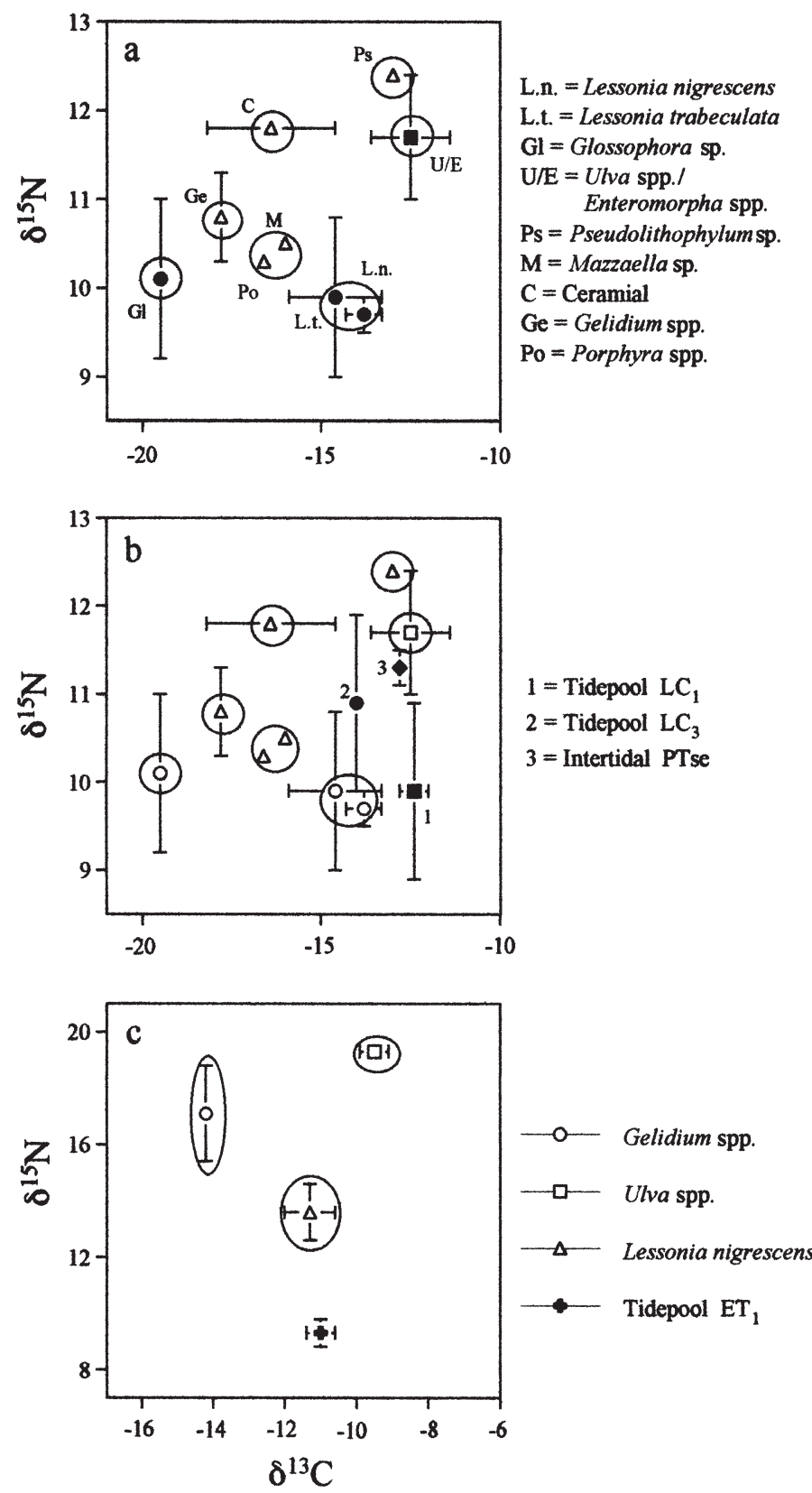

Fig. 3. Carbon and nitrogen stable isotope values of (a) different marine algae species of the central Chilean coast, (b) Tetrapygus niger individuals from tidepools of Las Cruces and PTse, and (c) T. niger individuals from a tidepool of El Tabo

The arrival of drift kelp showed important temporal variations. In general, the highest levels of arrival were observed during late spring, early summer and a large part of the autumn, while the lowest levels occurred during winter and early spring. This temporal pattern was constant in space (localities: Punta de Tralca and El Tabo, or environments: rocky substratum and tidepools) and time (years: 1996-1997 and 1997-1998 for

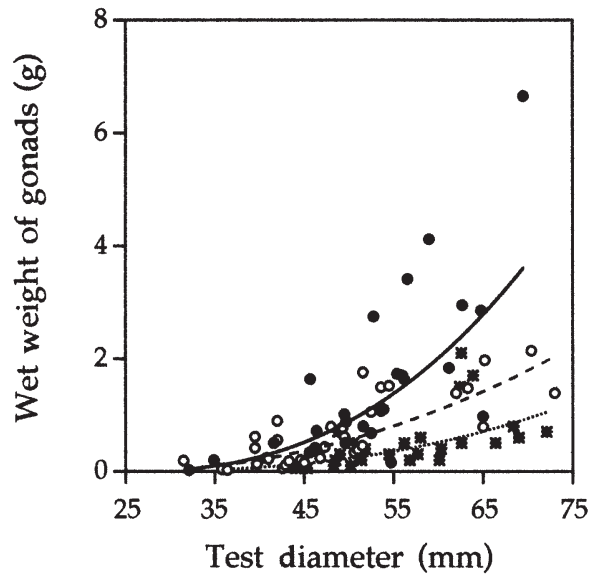

- High drift kelp availability $(\mathrm{N}=34)$ Tidepools $\mathrm{LC}_{2}$ and $\mathrm{LC}_{3}$ $\mathrm{G}=\left(3.46 \times 10^{-4}\right)(\mathrm{T}-25)^{2.438} \mathrm{r}^{2}=0.678 ; \mathrm{p}<0.001$

- High drift kelp availability $(\mathrm{N}=25)$ Tidepools $\mathrm{LC}_{1}$ and $\mathrm{LC}_{4}$ $\mathrm{G}=\left(9.36 \times 10^{-4}\right)(\mathrm{T}-25)^{1.984} \mathrm{r}^{2}=0.547 ; \mathrm{p}<0.001$

* Low intertidal PTse $(\mathrm{N}=27)$ $\mathrm{G}=\left(9.3 \times 10^{-5}\right)(\mathrm{T}-25)^{2.421} \mathrm{r}^{2}=0.570 ; \mathrm{p}<0.001$

Fig. 4. Tetrapygus niger. Relationship between the wet weight of gonads and the size of individuals in tidepools with high and low drift kelp availability, and at PTse (a site dominated by calcareous crustose algae). $\mathrm{G}=$ wet weight of gonads ( $\mathrm{g}$ ), $\mathrm{T}=$ test diameter $(\mathrm{mm})$

rocky substratum and tidepools respectively). Gerard (1976) showed that water movement was an important factor in explaining the temporal pattern of drift kelp arrival inside a Macrocystis pyrifera forest in California. The author observed that during calm periods (e.g. summer) the accumulation of algal material was high inside the forest reaching a maximum level during early autumn. However, the first storms decreased the algal accumulation inside the forest during late autumn and winter. It is likely that the intensity of water movement also plays an important role in determining the temporal variability of drift material on the central Chilean coast. For example, the low drift kelp accumulation during the winter in all sites could be explained by the high frequency of storms associated with this season (i.e. offshore drift).

Tetrapygus niger individuals were efficient in retaining under their bodies or among their spines the drift kelp fronds deposited in tidepools. Previous studies have considered this species unable to use drift algae as an important food item (Vásquez 1986, Contreras \& Castilla 1987), although this could be partly overcome by aggregation, i.e. formation of highdensity groups in zones with strong bottom currents (Vásquez \& Buschmann 1997). If we consider that in these studies hydrodynamics were high (in contrast to 
the low hydrodynamics of tidepools), it seems reasonable to suggest an important role of wave action in the utilization (capture and consumption) of drift kelp by T. niger. The relationship between hydrodynamics and food availability is supported by Lawrence et al. (1996), who found that guts of subtidal T. niger from a semi-exposed bay and a protected site were full of food, while those of individuals from a very exposed site were empty with few exceptions (all sites had a similar algal composition on the rocky bottom). The ability of $T$. niger to retain drift kelp underscores the need to re-evaluate the importance of this resource (see below). The role of hydrodynamics in the utilization of drift food should be considered in future studies.

For most of the year, drift algae were available in sufficient quantities to supply all the sea urchins' food (but see $\mathrm{LC}_{1}$ and $\mathrm{LC}_{4}$ ). The exception occurred during late winter and early spring, i.e. July-October, when drift kelp decreased. These temporal changes in drift kelp availability could generate seasonal changes in the diet of sea urchins, i.e. a decrease in drift kelp consumption and an increase in the consumption of benthic algae during late winter and early spring. This aspect should also be considered in future studies.

\section{Consumption of drift kelp by sea urchins and effects on gonad development}

Drift kelp represents an important food resource for a number of marine invertebrate species throughout the world (Gerard 1976, Harrold \& Reed 1985, Tutschulte \& Connell 1988, Kim 1992, Bustamante et al. 1995). On the central Chilean coast, the use of this resource has been traditionally associated only with the sea urchin Loxechinus albus, which has the morphological structures necessary to capture this kind of food (Contreras \& Castilla 1987). However, the dietary and stable isotope analyses presented here show that drift kelp is the main food item of intertidal individuals of Tetrapygus niger. Nearly $70 \%$ of food found in the stomach contents of intertidal T. niger individuals was the kelp Lessonia sp., followed by green algae (mainly Ulva spp., Enteromorpha spp. and Ulothrix sp.) and calcareous crustose algae with values ca. 22 and $3 \%$ respectively. The stable isotope analysis showed that a large part of the carbon assimilated by sea urchins of tidepools with high drift kelp Lessonia spp. arrival $\left(\mathrm{LC}_{2}, \mathrm{LC}_{3}\right.$ and $\left.\mathrm{ET}_{1}\right)$ was derived from this source. In tidepools or sites where the arrival of drift kelp was low or zero, e.g. $\mathrm{LC}_{1}$ and PTse, this resource was poorly used. In these cases, the sea urchins appeared to use and assimilate the most conspicuous algae of each habitat: green algae (Ulva spp. and Enteromorpha spp.) in the case of the tidepool $\mathrm{LC}_{1}$ and calcareous crustose algae in PTse (Table 1, Fig. 3).
It is well known that echinoids present a wide spectrum of phenotypic responses to environmental changes, especially to those which affect food availability. For example, in several sea urchin species the size of the Aristotle's lantern with respect to the body size changes in response to different levels of food availability (Ebert 1980, Black et al. 1984, Edwards \& Ebert 1991). Some studies have also suggested that some sea urchin species decrease in size in response to limited food resources (Levitan 1989, 1991) and that the development of gonadal tissue is limited by the amount and quality of food (Pearse 1981, Keats et al. 1984, RogersBennett et al. 1995, Russell 1998). This study did not find a relationship between drift food availability and the size of sea urchins. A lack of plasticity of the body form and spines as well as the Aristotle's lantern in relation to hydrodynamics and food availability has been previously described for Tetrapygus niger (Lawrence et al. 1996): this lack of plasticity could be related to the species' life-history strategy. Ebert (1988) suggested that life-history strategies are involved in the allometry, design and constraints of body components and of shape in echinoids. However, one would anticipate plasticity to be minimal in echinoid species with a stress-tolerant strategy (Lawrence 1990), which seems to be so in the case of $T$. niger (Lawrence et al. 1996). In this study a positive correlation was observed between the level of drift kelp in tidepools and the gonad size of $T$. niger individuals. This makes sense if we consider that sea urchins feeding on macroalgae show a higher gonad development than individuals feeding on crustose algae (see Keats et al. 1984), and that the gonad index of T. niger increases from summer to early autumn (Zamora \& Stotz 1993), which are the seasons of high drift kelp availability in central Chile (Figs. 1 \& 2). Moreover, the drift kelp availability in tidepools decreased from July to October, which are the months when $T$. niger reaches the peak of gonad maturity and spawning starts (Zamora \& Stotz 1993). The small gonad size of individuals in tidepools with low drift kelp availability (particularly individuals $>50 \mathrm{~mm}$ ), confirms that the maintenance of a large body size limits the energy available for reproduction when food resources are scarce (McShane \& Anderson 1997).

It is likely that a decrease in the energy for reproduction has important consequences for closed populations of Tetrapygus niger. For example, the larval settlement and recruitment could be affected, producing a decrease in the population size or even local extinction. A population decrease in this species could modify the community structure of tidepools, e.g. changes in cover and diversity of benthic algae adhered to rocks (see Scenario B in Fig. 5). This aspect should be considered in future studies. 
Kim (1992) demonstrated that the body size of a tubicolous polychaete was positively affected by the availability of drift kelp on the coast of California. The author postulated that the presence of large individuals could attract more and new predators or restrict the presence of large infaunic organisms, affecting the whole community. Bustamante et al. (1995) found a positive correlation between the presence of subtidal drift kelp and the biomass of limpets on the rocky intertidal coast of South Africa. The authors proposed that the high density of limpets could decrease the abundance and diversity of macroalgae, increase the cover of encrusting crustose algae and decrease the space occupied by filters-feeders, affecting thus the structure and function of the intertidal community. Vetter \& Dayton (1999) observed that large accumulations of drift algae in submarine canyons were associated with higher densities of megafaunal invertebrates and fishes. It is likely that the

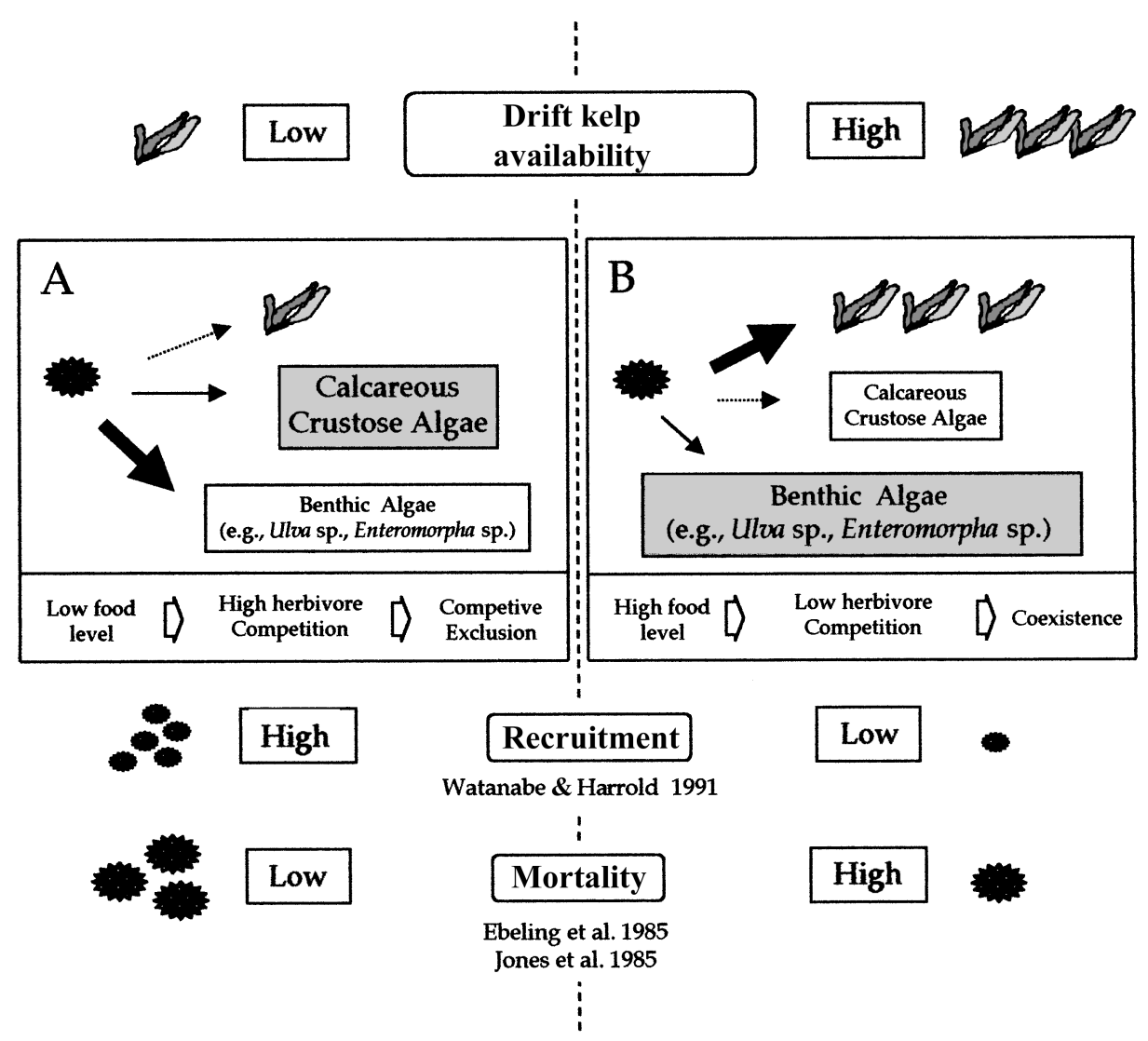

Fig. 5. Diagram showing 2 theoretical community patterns in tidepools depending on drift kelp availability. The availability level of this resource would generate similar patterns to those produced by recruitment or mortality of sea urchins

drift kelp arrival on the intertidal

zone and the consumption of this

resource by Tetrapygus niger individuals also have important consequences at the community level on the central Chilean coast. For example, the consumption of drift kelp could increase the abundance and taxonomic richness of other macroalgal species and decrease the cover of calcareous crustose algae in tidepools (see Andrew \& Underwood 1993 and Wootton 1995 for other sea urchin species). This could generate community patterns similar to those determined by low recruitment rates of juvenile sea urchins (Watanabe \& Harrold 1991) or high mortality levels of adult individuals (Ebeling et al. 1985, Jones et al. 1985; see Scenario B in Fig. 5). Thus, the availability of drift kelp to other grazers (e.g. herbivorous fishes) could increase in these environments, which could relax herbivore competition and allow their coexistence in tidepools (see Scenario B in Fig. 5). In contrast, the temporal absence of drift kelp could generate an important shift in the source from which the assimilated carbon is obtained, from kelp to green algae or to calcareous crustose algae. Here, it could be possible to see a different community pattern: low cover and taxonomic richness of benthic algae (probably a high cover of calcareous crustose algae), low availability of this resource to other grazers and an increase in herbivore competition (it could also prevent the coexistence of some of them) (see Scenario A in Fig. 5).

Trophic resources coming from border habitats are frequently found in marine communities. However, the consequences that the arrival and consumption of this kind of resource can have at population and/or community level are still poorly known. This study throws light on the importance of trophic subsidies in the feeding of intertidal species and their ecological consequences at different levels of biological organization in temperate environments. It also proposes 2 alternative theoretical community scenarios to be found in tidepools depending on the availability of drift resources. More extensive field studies will be necessary to confirm or refute some of these hypotheses.

Acknowledgements. This work was funded by FONDECYT grant 2960015. I thank Dr. Franz Smith and Dr. J. M. Fariña for constructive comments and helpful suggestions that greatly improved this manuscript. During the study, the author was a Fellow of Fundación Andes. 


\section{LITERATURE CITED}

Anderson WB, Polis GA (1998) Marine subsidies of island communities in the Gulf of California: evidence from stable carbon and nitrogen isotopes. Oikos 81:75-80

Andrew NL, Underwood AJ (1993) Density-dependent foraging in the sea urchin Cestrostephanus rodgersii on shallow subtidal reefs in New South Wales, Australia. Mar Ecol Prog Ser 99:89-98

Black R, Codd C, Hebbert D, Vink S, Burt J (1984) The functional significance of the relative size of Aristotle's lantern in the sea urchin Echinometra mathaei (de Blainville). J Exp Mar Biol Ecol 77:81-97

Bustamante RH, Branch GM, Aekhout S (1995) Maintenance of an exceptional grazer biomass on South African intertidal shores: trophic subsidy by subtidal kelps. Ecology 76 : 2314-2329

Castilla JC, Moreno CA (1981) Sea urchins and macroalgae: an experimental test of their ecological relations in southern Chile. In: Lawrence JM (ed) Echinoderms. Proc Int Echinoderm Conference, Tampa Bay. Balkema. Rotterdam, p 257-263

Contreras S, Castilla JC (1987) Feeding behavior and morphological adaptations in two sympatric sea urchin species in central Chile. Mar Ecol Prog Ser 38:217-224

Dayton PK, Currie V, Gerrodette T, Keller BD (1984) Patch dynamics and stability of some California kelp communities. Ecol Monogr 54:253-289

Dayton PK, Tegner MJ, Parnell PE, Edwards PB (1992) Temporal and spatial patterns of disturbance and recovery in a kelp forest community. Ecol Monogr 62:421-445

Duarte WE (1974) Orchestoidea tuberculata Nicolet, 1849 como organismo desintegrador de algas (Crustacea, Amphipoda, Talitridae). Not Mens Mus Nac Hist Nat (Santiago) 220/221:3-9

Ebeling AW, Laur DR, Rowley RJ (1985) Severe storm disturbances and reversal of community structure in a southern California kelp forest. Mar Biol 84:287-294

Ebert TA (1980) Relative growth of sea urchins jaws: an example of plastic resource allocation. Bull Mar Sci 30: $467-474$

Ebert TA (1988) Allometry, design and constraint of body components and of shape in sea urchins. J Nat Hist 22: 1407-1425

Edwards PB, Ebert TA (1991) Plastic response to limited food availability and spine damage in the sea urchin Strongylocentrotus purpuratus (Stimpson). J Exp Mar Biol Ecol 145: 205-220

Gerard VA (1976) Some aspects of material dynamics and energy flow in a kelp forest in Monterrey Bay, California. PhD thesis, University of California, Santa Cruz

Harrold C, Reed DC (1985) Food availability, sea urchin grazing and kelp forest community structure. Ecology 66 : 1160-1169

Inglis G (1989) The colonisation and degradation of stranded Macrocystis pyrifera (L.) C. Ag. by the macrofauna of a New Zealand sandy beach. J Exp Mar Biol Ecol 125: 203-217

Jones GM, Hebda AJ, Scheibling RE, Miller RE (1985) Histopathology of the disease causing mass mortality of sea urchins (Strongylocentrotus droebachiensis) in Nova Scotia. J Invertebr Pathol 45:260-271

Keats DW, Steele DH, South GR (1984) Depth-dependent reproductive output of the green sea urchin, Strongylocentrotus droebachiensis (OF Müller), in relation to the nature and availability of food. J Exp Mar Biol Ecol 80: $77-91$
Kim SL (1992) The role of drift kelp in the population ecology of a Diopatra ornata Moore (Polychaeta: Onuphidae) ecotone. J Exp Mar Biol Ecol 156:253-272

Larraín AP (1975) Los echinoideos regulares fósiles y recientes de Chile. Gayana Zool 35:1-189

Lawrence JM (1990) The effect of stress and disturbance on echinoderms. Zool Sci (Tokyo) 7:17-28

Lawrence JM, Vásquez J, Robbins BD, Vega A (1996) Lack of plasticity of the body form, Aristotle's lantern and spines of Tetrapygus niger (Echinodermata: Echinoidea). Gayana Oceanol 4:93-97

Levitan DR (1989) Density-dependent size regulation in Diadema antillarum: effects on fecundity and survivorship. Ecology 70:1414-1424

Levitan DR (1991) Skeletal changes in the test and jaws of the sea urchin Diadema antillarum in response to food limitation. Mar Biol 111:431-435

Magnum CP, Cox CD (1971) Analysis of the feeding response in the onuphid polychaete Diopatra cuprea. Biol Bull 145: 215-229

McConnaughey T, McRoy CP (1979) Food-web structure and the fractionation of carbon isotopes in the Bering Sea. Mar Biol 53:257-262

McShane PE, Anderson OF (1997) Resource allocation and growth rates in the sea urchin Evechinus chloroticus (Echinoidea: Echinometridae). Mar Biol 128:657-663

Muñoz M, Santelices B (1989) Determination of the distribution and abundance of the limpet Scurria scurra on the stipes of the kelp Lessonia nigrescens in Central Chile. Mar Ecol Prog Ser 54:277-285

Pearse JS (1981) Synchronization of gametogenesis in the sea urchins Strongylocentrotus purpuratus and S. franciscanus. In: Clark WH, Adams TS (eds) Advances in invertebrate reproduction. Elsevier North Holland, Amsterdam, p 53-68

Polis GA, Hurd SD (1995) Extraordinarily high spider densities on islands: flow of energy from the marine to terrestrial food webs and the absence of predation. Proc Natl Acad Sci USA 92:4382-4386

Polis GA, Holt RD, Menge BA, Winemiller KO (1995) Time, space, and life history: influences on food webs. In: Polis GA, Winemiller K (eds) Food webs: integration of patterns and dynamics. Chapman \& Hall, London, p 435-460

Polis GA, Anderson WB, Holt RD (1997) Toward an integration of landscape and food web ecology: the dynamics of spatially subsidized food webs. Annu Rev Ecol Syst 28: 289-316

Rau GH, Mearns AJ, Young DR, Olson RJ, Schafer HA, Kaplan IR (1983) Animal ${ }^{13} \mathrm{C} /{ }^{12} \mathrm{C}$ correlates with trophic level in pelagic food webs. Ecology 64:1314-1318

Roa R (1990) El efecto del tamaño y la estacionalidad sobre la preferencia alimentaria y la dieta natural del erizo Tetrapygus niger (Molina, 1782) de Chile Centro Sur. Master's thesis, Facultad de Oceanografía, Universidad de Concepción, Concepción

Roa R (1992) Design and analysis of multiple-choice feedingpreference experiments. Oecologia 89:509-515

Rogers-Bennett L, Bennett WA, Fastenau HC, Dewees CH (1995) Seasonal variation in red sea urchin reproduction and morphology: implications for harvest refugia. Ecol Appl 5:1171-1180

Rounick JS, Winterbourn MJ (1986) Stable carbon isotopes and carbon flow in ecosystems. Bioscience 36:171-177

Russell MP (1998) Resource allocation plasticity in sea urchins: rapid, diet induced, phenotypic changes in the green sea urchin, Strongylocentrotus droebachiensis (Müller). J Exp Mar Biol Ecol 220:1-14 
Simenstad CA, Duggins DO, Quay PD (1993) High turnover of inorganic carbon in kelp habitats as a cause of $\delta^{13} \mathrm{C}$ variability in marine food webs. Mar Biol 116:147-160

Sokal RR, Rohlf FJ (1995) Biometry: the principles and practice of statistics in biological research, 3rd edn. WH Freeman, New York

Tegner MJ, Dayton PK (1987) El Niño effects on southern California kelp forest communities. Adv Ecol Res 17:243-279

Tegner MJ, Dayton PK (1991) Sea urchins, El Niños, and the long term stability of southern California kelp forest communities. Mar Ecol Prog Ser 77:49-63

Tutschulte TC, Connell JH (1988) Feeding behavior and algal food of three species of abalone (Haliotis) in southern California. Mar Ecol Prog Ser 49:57-64

Vásquez JA (1986) Morfología de estructuras alimentarias como factores en la organización de comunidades submareales. Biota (Chile) 1:104

Vásquez JA (1993) Abundance, distributional patterns and diets of main herbivorous and carnivorous species associated to Lessonia trabeculata kelp beds in northern Chile. Serie Ocasional, Facultad de Ciencias del Mar, Universidad Católica del Norte 2:213-229

Editorial responsibility: Otto Kinne (Editor), Oldendorf/Luhe, Germany
Vásquez JA, Buschmann AH (1997) Herbivore-kelp interactions in Chilean subtidal communities: a review. Rev Chil Hist Nat 70:41-52

Vásquez JA, Castilla JC, Santelices B (1984) Distributional patterns and diets of four species of sea urchins in giant kelp forest (Macrocystis pyrifera) of Puerto Toro, Navarino Island, Chile. Mar Ecol Prog Ser 19:55-63

Vetter EW, Dayton PK (1999) Organic enrichment by macrophyte detritus, and abundance patterns of megafaunal populations in submarine canyons. Mar Ecol Prog Ser 186: $137-148$

Watanabe JM, Harrold C (1991) Destructive grazing by sea urchins Strongylocentrotus spp. in a central California kelp forest: potential roles of recruitment, depth, and predation. Mar Ecol Prog Ser 71:125-141

Wootton JT (1995) Effect of birds on sea urchins and algae: a lower-intertidal trophic cascade. Ecoscience 2: $321-328$

Zamora S, Stotz W (1993) Ciclo reproductivo de Tetrapygus niger (Molina 1782) (Echinodermata: Echinoidea) en dos localidades de la IV Region, Coquimbo, Chile. Rev Chil Hist Nat 66:155-169

Submitted: December 8, 1999; Accepted: October 9, 2002 Proofs received from author(s): March 27, 2003 